\title{
Hyperbaric oxygen therapy in wound healing in mice
}

[Oxigenoterapia hiperbárica na cicatrização de feridas em camundongos ]

\author{
B.P. Amaral ${ }^{1}$, A. Krause², J.S. Pasini ${ }^{3}$, Á.J.C. Silva ${ }^{4}$, M.A. Inkelmann ${ }^{5}$, D.C.M. Müller ${ }^{2 *}$ \\ ${ }^{1}$ Aluna de pós-graduação - Universidade Federal de Santa Maria (UFSM) - Santa Maria, RS \\ ${ }^{2}$ Universidade Federal de Santa Maria (UFSM) - Santa Maria, RS \\ ${ }^{3}$ Programa de Residência - Universidade Federal de Santa Maria (UFSM) - Santa Maria, RS \\ ${ }^{4}$ National Autonomous University of Nicaragua - León, Nicaragua \\ ${ }^{5}$ Universidade Regional do Noroeste do Estado do Rio Grande do Sul - Ijuí, RS
}

\begin{abstract}
We investigated the local and systemic effects of hyperbaric oxygen therapy in BALB/C mice, exposed to two different exposure times, under 2.4 atmosphere (ATM). Fifteen animals were divided into three groups (GI, GII and Control) and underwent a surgical excision of a skin fragment of approximately one square centimeter of the dorsal region. The wounds were treated and monitored for 21 days. In the control group, the wound was cleaned once a day with sterile $0.9 \% \mathrm{NaCl}$ solution. GI and GII mice were submitted to daily hyperbaric oxygen therapy of 30 or 60 minutes sessions, respectively. The wounds were photographed every three days and their surfaces were analyzed by an image analyzer. At 21 days, all animals were euthanatized for histopathological analysis of the skin, lungs and liver in order to identify eventual alterations in wound healing or in the analyzed organs. Animals belonging to GI showed a faster skin wound healing in comparison to the other groups. Animals from GII, however, showed a delayed wound healing process and exhibited lung and microcirculatory alterations. These findings allow us to conclude that the exposure time to the oxygen in hyperbaric environment is crucial and can help or disturb skin wound healing or even be deleterious to other organs.
\end{abstract}

Keywords: regeneration, adjuvants, skin lesions

\section{RESUMO}

Investigaram-se os efeitos locais e sistêmicos da oxigenoterapia hiperbárica em camundongos BALB / C, submetidos a dois tempos de exposição diferentes, sob atmosfera 2,4 (ATM). Quinze animais foram divididos em três grupos (GI, GII e controle) e submetidos à excisão cirúrgica de fragmento de pele de aproximadamente um centímetro quadrado da região dorsal. As feridas foram tratadas e acompanhadas por 21 dias. No grupo controle, a ferida foi limpa uma vez ao dia, com solução estéril de $\mathrm{NaCl} \mathrm{0,9 \% .}$ Camundongos GI e GII foram submetidos à oxigenoterapia hiperbárica diária de 30 ou 60 minutos de sessões, respectivamente. As feridas foram fotografadas a cada três dias, e suas superfícies analisadas por um analisador de imagens. Aos 21 dias, todos os animais foram submetidos à eutanásia para análise histopatológica da pele, do pulmão e do fígado, em busca de eventuais alterações na cicatrização da ferida ou nos órgãos analisados. Animais pertencentes ao GI apresentaram cicatrização mais rápida de feridas cutâneas em comparação aos outros grupos. Já os animais do GII apresentaram retardo na cicatrização da ferida e alterações pulmonares e microcirculatórias. Esses achados permitem concluir que o tempo de exposição ao oxigênio em ambiente hiperbárico é fundamental e pode auxiliar ou atrapalhar a cicatrização de feridas cutâneas ou mesmo ser deletério para outros órgãos.

Palavras-chave: regeneração, adjuvantes, lesões cutâneas

Recebido em 21 de agosto de 2019

Aceito em 1 de setembro de 2020

*Autor para correspondência (corresponding author)

E-mail: mullerdcm@gmail.com 


\section{INTRODUCTION}

Clinical management of cutaneous wounds has great relevance in veterinary medicine, especially in extensive lesions and in patients with healing disorders, such as diabetics (Vermeulen et al., 2005; Waldron and Zimmerman-Pope, 2007). Hyperbaric oxygen therapy (HBOT) has been used in wound treatment and consists in the administration of a breathing fraction of pure oxygen $(100 \%)$ in a hyperbaric environment, with pressure higher than atmospheric at sea level. The elevation of two to three times the atmospheric pressure results in an increase of arterial and tissue oxygen concentration, triggering physiological and therapeutic effects (Ulkur et al., 2007). Previous studies observed that HBOT increases tissue tolerance to ischemia and reduces their effects, improves tissue microcirculation by reducing platelet aggregation and increasing plasma capacity to transport oxygen to the capillary extremities. It has antioedematose, antimicrobial and antibacterial effects (Kiumehr et al., 2005; Millar et al., 2015).

In injured tissues, along with contributing to the reversion of hypoxia, HBOT stimulates the formation of the collagen matrix, which is essential for angiogenesis and healing (Kiumehr et al., 2005; Zhang et al., 2007). Zhang et al. (2007) studied the effects of HBOT associated to conventional wound healing treatment in rats and observed a reduced healing time, which could decrease treatment costs of the patients.

The effects of pressure oscillations, however, may lead to barotraumatic events, with most frequently described lesions in tympanums, paranasal sinuses, lungs and hollow organs. Pulmonary toxicity can also occur after prolonged exposure to hyperbaric oxygen (Olszewer, 2008, Lima et al., 2014). For all these reasons, the importance of establishing safe protocols for patients undergoing hyperbaric therapy is highlighted (Kiumehr et al., 2005). In this study, we built a hyperbaric chamber in order to evaluate the effects of hyperbaric oxygen therapy on the wound healing in $\mathrm{BALB} / \mathrm{C}$ mice and tested different HBOT exposure times.

\section{MATERIALS AND METHODS}

The project was approved by the Committee on Ethics in the Use of Animals (CEUA) of the Regional University of the Northwest of the State of Rio Grande do Sul - UNIJUÍ, Ijuí, RS, according to the National Council for Control of Animal Experimentation (CONCEA), under protocol number 003/2013. In order to obtain hyperbaric conditions, we designed and built a hyperbaric chamber, with an iron cylinder with $0.058 \mathrm{~m}^{3}$ (58 liters), a digital and analog gas flowmeter for pressure control and maintenance (0-5 ATM), an internal temperature monitoring system and a safety valve. The chamber was also connected with a mobile computer camera, which allowed the permanent monitoring and recording the animals during exposure to the hyperbaric environment.

To illuminate the chamber, we used LED lamps, in order to avoid heat generation and to prevent possible explosions of the oxygen. An internal filter containing soda lime, which was changed when saturated with the gas, absorbed the $\mathrm{CO} 2$ generated by the breathing of the mice. Fifteen Specific Pathogen Free (SPF) isogenic BALB/C mice (Musmusculus) were divided into three groups of five each. The mice were housed in cages with sterilized shavings, water and food ad libitum, in a controlled environment with as Table temperature of $22^{\circ} \mathrm{C}$, relative air humidity between $50-55 \%$ and a light/dark cycle of $12 / 12$ hours.

In order to study the effect of hyperbaric conditions on wound healing, we produced skin lesions surgically in mice. Pre-anesthetic medication consisted of ketamine hydrochloride (50mg.kg ${ }^{-1}$ ) and midazolam (1 mg. $\left.\mathrm{kg}^{-1}\right)$, followed by trichotomy of the interscapular region. Anesthesia was induced and maintained with isoflurane administered with a facial mask. Antiinflammatory therapy consisted of ketoprofen $\left(1.5 \mathrm{mg} \cdot \mathrm{kg}^{-1}\right)$ preoperatively and extended for two more days, every 24 hours. After antisepsis and under anesthesia, a circular $10 \mathrm{~mm}$ diameter skin fragment was removed using a biopsy punch. Subsequently, the animal was kept under observation in the surgical room until complete recovery from anesthesia. The wound treatments were performed for 21 days after surgery and the images of each lesion were obtained on the day of the procedure and every three subsequent 
days, always maintaining the same optical and focal distance, and resolution of the camera.

For treatment, the mice were divided in three groups: control group (CG), the wounds were cleaned with sterile $0.9 \% \mathrm{NaCl}$ water solution and gauze cover; group I (GI) and group II (GII) animals had the lesions cleaned with sterile $0.9 \%$ $\mathrm{NaCl}$ water solution and gauze and then placed in the hyperbaric chamber for 30minutes and 60 minutes, respectively. On the twenty-first day of treatment, animals were euthanized, and lungs, heart, kidneys, liver and scar fragment of the cutaneous lesion samples were collected for histopathological evaluation.

The fragments were fixed in $4 \%$ paraformaldehyde solution and stained with hematoxylin-eosin and masson's Trichrome for microscopic evaluation. In addition, the wound regression in different treatments was compared by the size of the lesions during the treatment. For this parameter, we estimate the area in square millimetres $\left(\mathrm{mm}^{2}\right)$ using an image analyze software (Matlab, Version 7.9.0, mathWorks, USA). The obtained values were transformed into percentage, standardizing the wound area at day zero, as $100 \%$. From the percentage data, the means were compared by univariate analysis using the Scott-Knott test.

\section{RESULTS AND DISCUSSION}

There are several hyperbaric oxygen therapy protocols to stimulate wound healing, with pressures ranging from 1 to 3 ATM and exposure times of up to 180minutes (Flegg et al., 2010). In our study, exposure times to HBOT were 30 (GI) and 60minutes (GII), under 2.4 ATM. Table 1 represents the percentage reduction in wound area for the different groups throughout the experiment and evidences the highest reduction in GI $(\mathrm{P}<0.05)$. By observing the Table 1 it is possible to see a better response of wound reduction in the control group on day 3 $(57.85 \%)$, in comparison to 77.66 and 79.68 reduction in GI and GII, respectively. On days 9 and $12 \mathrm{GI}$ and control saline solution group presented a similar wound evolution and, from day 15 to day 18 , the GI showed the highest wound reduction in comparison to GII and control group.

Table 1. Analysis of wound healing in BALB/C mice by relative reduction of wound areas $\left(\mathrm{mm}^{2}\right)$ in two different exposure times (30 and 60minutes) of Hyperbaric Oxygen Therapy (HBOT), and control at 3, 6, 9, 12 and 18 days post-surgery. The numbers in the columns refer to the relative reduction $(\%)$ of the wound area for each day. Analysis of averages by Scott \& Knott

\begin{tabular}{lcccccc}
\hline \multirow{2}{*}{ Treatment } & \multicolumn{5}{c}{ Day } \\
\cline { 2 - 7 } & 3 & 6 & 9 & 12 & 15 & 18 \\
\hline Oxygen. Hyper. 30min* & $77.66^{\mathrm{b}}$ & $61.49^{\mathrm{a}}$ & $35.81^{\mathrm{a}}$ & $11.65^{\mathrm{a}}$ & $6.37^{\mathrm{a}}$ & $0.82^{\mathrm{a}}$ \\
Oxygen. Hyper. 60min & $79.68^{\mathrm{b}}$ & $64.7^{\mathrm{a}}$ & $52.63^{\mathrm{b}}$ & $24.41^{\mathrm{b}}$ & $14.7^{\mathrm{c}}$ & $2.05^{\mathrm{b}}$ \\
Control - SS & $57.85^{\mathrm{a}}$ & $48.97^{\mathrm{a}}$ & $34.23^{\mathrm{a}}$ & $17.8^{\mathrm{a}}$ & $10.77^{\mathrm{b}}$ & $1.71^{\mathrm{b}}$ \\
\hline
\end{tabular}

*Min minute; averages followed by the same letter in the column did not differ significantly by the Scott \& Knott test at the $5 \%$ error probability level. SS: saline solution $(0,9 \% \mathrm{NaCl})$.

The Figure 1 illustrates representative images of the progress of wound healing of the three groups GI, GII and Control - saline solution) at three different stages (days 0, 9 and 21). GI mice presented complete wound healing at day 18 (Figure 1-A3), in comparison to GII (Figure 1B3) and control group (Figure 1-C3). In addition, the reduction of GI lesions in comparison to the other groups is evident and significant already on the 15th day of evaluation (Table 1). Oxygen, when offered in high concentrations, associated to the hyperbaric environment, resulted in greater arterial and tissue distribution, favoring oxygenation to the ischemic regions (Tibbles and Edelseberg, 1996). 


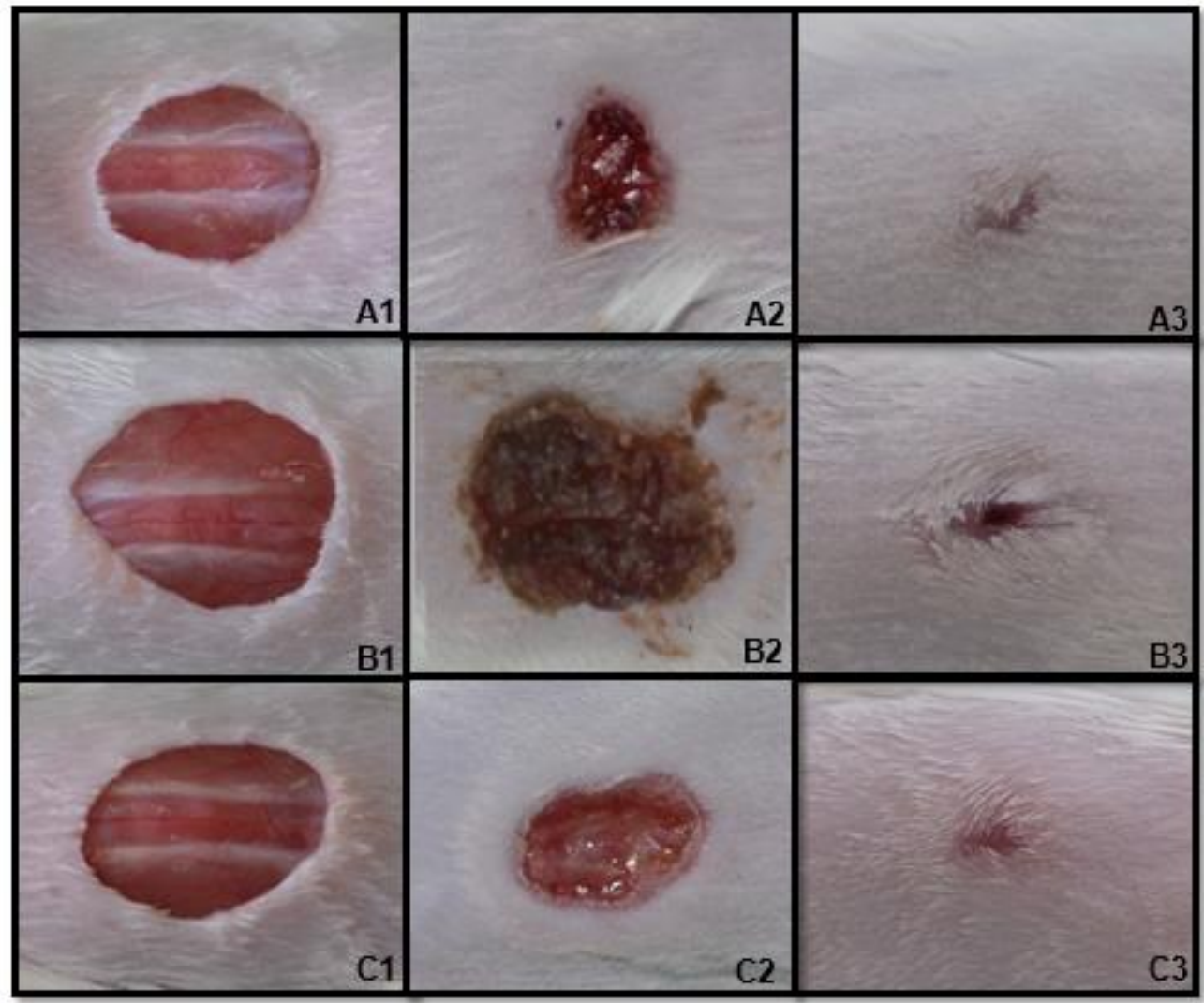

Figure 1. Wound healing in three different groups: A, GI group, treated with Hyperbaric Oxygen Therapy (HBOT) for 30 minutes; B, GII group, treated with HBOT for 60 minutes and C, control group, treated with sterile $\mathrm{NaCl} 0,9 \%$ saline solution. (A1, B1 and $\mathrm{C} 1$ ), at nine days (A2, B2 and C2) and at 21 days (A3, B3 and C3), respectively.

The histopathological analysis of biopsies collected on the 21 st day of treatment, revealed a discrete mononuclear infiltrate, with the formation of granulation tissue composed of vessels and collagen, with no presence of inflammatory cells in GI and in control samples. According to (Zhang et al., 2007), oxygen supplied in large amounts, during adequate time, promotes the diffusion of gas at distances up to four times higher, reaching low oxygenated tissues. In the presence of higher $\mathrm{O}_{2}$ concentrations, the fibroblasts stimulate angiogenesis, collagen matrix synthesis and growth of structural cells of the skin. Oxygen is crucial to the hydroxylation of lysine and proline, a fundamental step in the synthesis of collagen, angiogenesis and epithelization (Zhang et al., 2007).

An opposite effect of HBAT was observed in GII, when the time of exposure was 60 minutes, suggesting a deleterious effect of higher exposure times for healing. As shown in Table 1, from the ninth day of evaluation, animals exposed to 60 minutes of daily HBOT had a slower wound healing in comparison to GI and control group. This was also evidenced in histopathology of biopsies at 21 days, where a moderate presence of collagen in the superficial dermis, a marked inflammatory mononuclear infiltrate, as well as hemorrhagic areas due to rupture of blood capillaries was seen.

No histopathological alterations were observed in the kidneys, heart and liver in any group. However, the lungs, of GII mice presented moderate multifocal congestion, moderate presence of mononuclear inflammatory cells in the perivascular and peribronchiolar regions, although the cells were preserved and no oedema was present. According to Buras (2000) the respiratory system is sensitive to changes in 
atmospheric pressure. In the lungs, bleeding, inflammation and emphysema can occur during exposure to excessive HBOT. In hyperbaric medicine, these changes are called pulmonary barotraumas and initially manifest as tracheobronchitis (transient with cessation of exposure), which, with continued exposure, progresses to acute respiratory distress syndrome and, finally, interstitial pulmonary fibrosis (Obiagwu et al., 2015).

Based on the three proposed treatments of clean open wounds, the evolution of healing for 21 days was evaluated. We observed that three days after the injury, animals treated with sterile saline solution of $\mathrm{NaCl} 0,9 \%$ presented a better reduction of the wound to those treated with HBOT. This inflammatory phase of healing occurs in the first three days after the injury. It starts on the first day and extends to the third after the injury and is characterized by the migration of defense cells to the lesion, whose functions are phagocytosis of bacteria and foreign bodies and the development of granulation tissue (Mandelbaum et al., 2003). The cells are attracted by moisture, a fact that facilitates the diapedesis towards the lesion (Fazio et al., 2000). Considering that the hyperbaric oxygen therapy sessions resect the exposed surface, it is conceivable that this dryness was responsible for the reduction of cellular migration and initial delay in healing, as observed.

The second stage of healing is debridement, which extends until the sixth day after the injury. It has the function of clearing the region, cleaning contaminated wounds (Townsend et al., 2014). The model we used here was the surgical wound, resulting in clean wounds with a very low degree of contamination, and, consequently, the debridement phase practically did not occur, evolving rapidly to the next step of wound healing, the proliferation stage. In Table 1 it is possible to observe that there is no difference between the three groups on day six, precisely because it is an equal condition among the animals, all having clean wounds.

The proliferation phase begins after wound cleansing and extends to the 14th day after injury and is the beginning of the closure of the injury (Townsend et al., 2014). Keratinocytes move attracted by moisture from the wound bed, as previously mentioned. Therefore, fibroplasia and the formation of the matrix begins, resulting in granulation tissue. The formation of this tissue depends on the fibroblast, which produces not only collagen, but also elastin, fibronectin, glycosaminoglycans and proteases, responsible for physiological remodeling (Mandelbaum et al., 2003).

Even at this stage, angiogenesis occurs to increase the supply of oxygen and nutrients for healing (Fazio et al., 2000). The primary basic stimulus for onset of angiogenesis is hypoxia. Considering that HBOT causes an increase in the pressure gradient between injured tissues and healthy tissues, with healthy tissues being more oxygenated than those injured, this relative hypoxia acts as a stimulus for the onset of angiogenesis (Lima et al., 2001). In the histological evaluation of the skin, it was possible to observe a higher number of micro vessels in the animals submitted to HBOT in comparison to the control group.

However, on the 15 th day of treatment, wound aspect of GII was worse compared to the other groups, with hemorrhagic spots and blackened staining in the cutaneous lesions, as well as irregularities at the edges on the wounds' edges. These signs suggest that prolonged exposure of open wounds to HBOT can cause increased tissue dryness. In these animals, a discrete cyanosis of the skin and mucous membranes was observed. Experimental studies have shown that HBOT generates transient vasoconstriction secondary to elevated tissue oxygen pressure and can be extended according to the time of exposure. According to Nylander et al. (1985), this transient vasoconstriction is beneficial, by its action in preventing oedema formation. Our results suggest that the degree of vasoconstriction may negatively influence healing, since they were observed only in GII.

The last stage of healing is recognized as remodeling or maturation, and occurs in collagen and matrix, lasting from 14 days to one year. It exhibits action on the tensile strength of the skin and decrease in the size of the scar and erythema. The neovasculature decreases and, over time, the scar is considered avascular (Fazio et al., 2000). In this study, although the animals were evaluated until 21 days after the procedures, at the 18th day, only the GI lesions were considered 
macroscopically healed, with small portions of granulation tissue. At 21 days, all injuries were considered healed macroscopically. This finding suggests an acceleration of the healing process in GI group in comparison to GII and control group. In addition, the time of exposure to hyperbaric conditions is an important parameter to be considered.

\section{CONCLUSION}

Based on our results, we conclude that HBOT time is crucial for the results, since 30minutes exposure allowed a shorter time of wound healing in comparison to control, and an exposure of 60minutes had the opposite effect. HBOT is a promising therapy for wound healing and protocols should be established for different animal species.

\section{REFERENCES}

BURAS, J. Basicmechanisms of hyperbaric oxygen in the treatment of ischemic-reperfusion injury. Anesthosiol. Clin., v.1, p.91-109, 2000.

FAZIO, M.J.; ZITELLI, J.A.; GOSLEN, J.B. Cicatrização de feridas. In: COLEMAN III W.P.; HANKE, C.W.; ALT, T.H.; ASKEN, S. Cirurgia cosmética - princípios e técnicas. 2.ed. Rio de Janeiro: Revinter, 2000. p.18-23.

FLEGG, J.A.; MCELWAIN, D.L.S.; BYRNE, H.M. Mathematical model of hyperbaric oxygen therapy applied to chronic diabetic wounds. Bull. Math. Biol., v.72, p.1867-1891, 2010.

Int. Arch. Otorhinolaryngol., v.18, p.204-09, 2014.

KIUMEHR, S.; DEMEHRI, S.; RABBANI, S. Preconditioning of the rat random-pattern skin flap:modulation by opioids. Br. J. Plast. Surg., v.58, p.58-64, 2005.

LIMA, E.B.; MARTINS, A.C.G.; BERNADES, C.H.A. Uso da câmara hiperbárica no tratamento do pé diabético. Rev. Angiol. Cir. Vasc., v.10, p.11-14, 2001.

LIMA, M.A.R.; FARAGEL, L.; LANCIA, M.C.; BAHAMED, F. Update on middle ear barotrauma after hyperbaric oxygen therapyInsights on Pathophysiology.
MANDELBAUM, S.H.; DI SANTIS, E.P.; MANDELBAUM, M.H.S. Cicatrização: conceitos atuais e recursos auxiliares. Parte 1. An. Bras. Dermatol., v.78, p.393-410, 2003.

MILLAR, I.L.; MCGINNES, R.A.; WILLIAMSON, O. et al. Hyperbaric oxygen in lower limb trauma (HOLLT); protocol for a randomised controlled trial. BMJ Open, v.5, p.1$10,2015$.

NYLANDER, G.; LEWIS, D.; NORDSTÖM, H.; LARSSON, J. Reduction of postischemic edema with hyperbaric oxygen. Plast. Reconstr. Surg., v.76, p.596-601, 1985.

OBIAGWU, C.; PAUL, V.; CHADHA, S. et al. Acute pulmonary edema secondary to hyperbaric oxygen therapy. Oxf. Med Case Reports, v.2, p.183-184, 2015.

OLSZEWER, E. Toxicidade do oxigênio. In__. Conceitos de medicina hiperbárica de baixa pressão. São Paulo: Santos, 2008. p.37-41.

TIBBLES, P.M.; EDELSBERG, J.S. Hyperbaricoxygen therapy. N. Engl. J. Med., v.334, p.16421648, 1996.

TOWNSEND, C.S.; BEAUCHAMP, D.E.; MARX, M.K. Tratado de cirurgia. 19.ed. São Paulo: Elsevier, 2014. 2240p.

ULKÜR, E.; KARAGOZ, H.; ERGUN O. et al. The effect of hyperbaric oxygen therapy on the delay procedure. Plast. Reconstr. Surg., v.119, p.86-94, 2007.

VERMEULEN, H.; UBBINK, D.T.; GOOSSENS, A. et al. Systematic review of dressings and topical agents for surgical wounds healing by secondary intention. Br. J. Surg., v.6, p.665-672, 2005.

WALDRON, D.R.; ZIMMERMAN-POPE, N. Ferimentos cutâneos superficiais. In: SLATTER, D. Manual de cirurgia de pequenos animais. 3ed. São Paulo: Manole, 2007. p.259-273.

ZHANG, T.; GONG, W.; LI, Z. et al. Efficacy of hyperbaric oxygen on survival of random pattern skin flap in diabetic rats. Undersea Hyperb. Med., v.34, p.335-339, 2007. 